JURNAL RISET KESEHATAN NASIONAL

VOL. 5 NO. 2 Halaman 87-93

$P$ - ISSN : 2580-6173

E-ISSN : 2548-6144

Available Online http://ojs.itekes-bali.ac.id/index.php/jrkn/index

\title{
HUBUNGAN ANTARA BODY IMAGE DENGAN POLA MAKAN REMAJA PUTRI KELAS XI DI SMK PGRI 4 DENPASAR
}

\section{(Correlation Between Body Image and Eating Pattern of Female Teenagers in Grade XI SMK PGRI 4 Denpasar)}

\author{
Kadek Yuni Kartika*, IGN Kusuma Negara ${ }^{* *}$, Sarah K. Wulandari*** \\ $\left.\left.{ }^{*}\right){ }^{* *}\right)^{* * *}$ Institut Teknologi dan Kesehatan Bali \\ E-mail: yunikartika@gmail.com
}

\begin{abstract}
ABSTRAK
Latar Belakang: Pola makan yang buruk pada remaja akan memicu terhambatnya proses pertumbuhan dan perkembangan (growth spurt) akibat dari ketidakseimbangan asupan zat gizi pada remaja.

Metode: Desain yang digunakan dalam penelitian ini adalah analitik korelasi dengan metode pendekatan cross sectional study. Populasi dalam penelitian ini adalah seluruh remaja putri kelas XI SMK PGRI 4 Denpasar dengan jumlah sampel 109 responden. Teknik pengambilan sampel dalam penelitian ini menggunakan metode Nonprobability Sampling dengan teknik Total Sampling. Pengumpulan data dilakukan secara online menggunakan kuesioner dalam link google form.

Hasil: Hasil temuan menunjukkan pada body image remaja putri kelas XI di SMK PGRI 4 Denpasar terdapat 55\% dalam kategori negatif, dan pola makan remaja putri kelas XI di SMK PGRI 4 Denpasar terdapat 53,2\% dalam kategori buruk. Selain itu juga, terdapat korelasi kuat antara dua variable, $r=0.710, n=109, p<0.005$.

Kesimpulan: Terdapat hubungan yang bermakna antara body image remaja putri dengan pola makan remaja putri. Semakin positif body image remaja putri maka pola makan remaja putri semakin baik.
\end{abstract}

Kata kunci: Body Image, Pola Makan, Remaja Putri

\section{ABSTRACT}

Background: A poor diet in teenagers will trigger the inhibition of the growth and development process (growth spurt) due to an imbalance in nutrient intake in teenagers.

Methods: The design used in this research was correlation analytic with cross sectional study approach. The population in this study were all female teenagers in grade XI SMK PGRI 4 Denpasar with a total sample of 109 respondents. The sampling used in this study was non-probability sampling method with total sampling technique. Data were collected online by using a questionnaire which was developed in the google form.

Results: The findings showed that 55\% of the grade XI female teenagers in SMK PGRI 4 Denpasar had negative body image and 53\% of these female teenagers also had bad eating patterns. It was also found that there was a strong correlation between the two variables $(r=0.710, n=109, p<0.005)$.

Conclusion: There is a significant correlation between the body image and eating patterns of the female teenagers. The more positive of body image, the better of eating patterns from the female teenagers.

Keywords: Body Image, Eating Patterns, Female Teenagers 


\section{LATAR BELAKANG}

Menurut Badan Kependudukan dan Keluarga Berencana (BKKBN) dalam Kementrian Kesehatan Republik Indonesia (2015), rentang usia remaja adalah 10-24 tahun dan belum menikah. Masa remaja merupakan masa peralihan manusia dari anak -anak menuju dewasa yang mana terjadinya periode pertumbuhan dan perkembangan yang pesat baik secara fisik, psikologis, maupun intelektual sehingga kebutuhan makanan yang mengandung zat-zat gizi menjadi cukup besar (Sari Pediatri, 2010 dalam Batubara, 2016).

Data yang tersedia menunjukkan di Indonesia bahwa lebih dari sepertiga remaja Indonesia mengonsumsi buah kurang dari sebulan sekali, lebih dari setengah remaja tidak mengonsumsi sarapan di rumah, dan sebagian besar remaja melewatkan sarapan (UNICEF Indonesia, 2019). Seharusnya agar mampu hidup sehat dan produktif para remaja wajib mengonsumsi makanan dalam jumlah yang cukup dan beragam dengan jadwal makan yang teratur. Pengaruh gaya hidup modern juga memberi dampak pada pola makan remaja (Sayogo, 2002 dalam Ritonga, 2014).

Pola makan atau perilaku makan adalah suatu tingkah laku observasi yang dilakukan individu dalam rangka memenuhi kebutuhan makan yang merupakan kebutuhan dasar yang bersifat fisiologis (Mardalena, 2017). Menurut Almatsier (2011) dalam Gloria (2019), menyatakan bahwa secara garis besar hal-hal yang dapat mempengaruhi pola konsumsi seseorang adalah sosial budaya dan lingkungan, pengetahuan, iklan, citra diri, agama dan kepercayaan. Selain itu juga, menurut Sulistyoningsih (2012) dalam Rahman, Dewi, \& Armawaty (2016) menekankan bahwa faktor yang dapat memengaruhi pola makan remaja antara lain: pendapatan orang tua, teman sebaya, serta pengetahuan gizi remaja tersebut.

Pola makan remaja yang tergambar dari data Global School Health Survey tahun 2015, antara lain: tidak selalu sarapan $(65,2 \%)$, sebagian besar remaja kurang mengonsumsi serat sayur buah $(93,6 \%)$ dan sering mengonsumsi makanan berpenyedap $(75,7 \%)$. Diantara remaja itu juga kurang melakukan aktivitas fisik (42,5\%). Apabila cara konsumsi ini berlangsung terus menerus dan menjadi kebiasaan pola makan tetap para remaja, maka akan meningkatkan risiko terjadinya penyakit tidak menular (Kemenkes RI, 2018). Hasil penelitian yang dilakukan oleh Suryani, Hafiani, \& Junita (2015) dalam jurnal kesehatan masyarakat Andalas di Bengkulu menjelaskan dari 1200 orang remaja pola makan baik berjumlah 249 $(20,8 \%)$ dan pola makan buruk berjumlah $951(79,2 \%)$. Selain itu juga, berdasarkan penelitian yang telah dilakukan oleh Gloria (2019) pada remaja di sekolah menengah pertama daerah Sumatera Utara menjelaskan bahwa dari 45 remaja hasil pola makan baik berjumlah 20 orang $(44,4 \%)$ dan pola makan tidak baik berjumlah $25(55,5 \%)$. Sedangkan, pola makan pada siswa kelas XI SMK N 4 Yogyakarta yang diteliti oleh Mulyati (2018) dengan food recall pada 51 responden menunjukkan kategori baik sejumlah 8 responden $(15,69 \%)$, kategori cukup sejumlah 29 responden $(56,86 \%)$, kategori kurang sejumlah 11 responden $(21,57 \%)$, dan kategori rendah sebanyak 3 responden $(5,88 \%)$. Jadi, dapat disimpulkan bahwa pola makan remaja di Indonesia masih tergolong buruk

Dampak yang akan ditimbulkan jika terjadi pola makan yang buruk yaitu terhambatnya proses pertumbuhan dan perkembangan (growth spurt) akibat dari ketidakseimbangan asupan zat gizi pada remaja. Khususnya bagi remaja perempuan, terkadang memiliki diet bagi tubuhnya sendiri akibat dari tekanan sosial untuk mempunyai bentuk fisik yang kurus dan stigma obesitas bisa menyebabkan praktik makan tak sehat ini terus dilakukan (Mardalena, 2017). Berawal dari penampilan fisik, remaja mulai memberikan gambaran dan persepsi tentang bentuk fisik yang dimiliki, kemudian beranjak pada penampilan fisik yang dimiliki orang lain hingga standar tubuh yang harus dimiliki setiap perempuan (Denich \& Ifdil, 2015). Gambaran dan persepsi tentang penampilan fisik inilah yang disebut body image. Body image adalah istilah yang luas yang mengacu pada persepsi, pikiran, dan perasaan seseorang tentang tubuhnya (Neagu, 2015).

Berdasarkan latar belakang dan hasil dari studi pendahuluan yang dilakukan oleh peneliti di SMK PGRI 4 Denpasar terhadap 10 siswi melalui aplikasi Whatsapp dengan link google form yang berisikan pertanyaan terkait body image dan pola makan menunjukkan bahwa $60 \%$ pola makan masih tergolong buruk karena memperhatikan body image dan takut akan gemuk, serta $40 \%$ pola

Jurnal Riset Kesehatan Nasional hal. 88 
makan siswi cukup baik dan cukup memperhatikan body image. Sehubungan dengan hal itu, peneliti tertarik untuk meneliti tentang hubungan antara body image dengan pola makan remaja putri kelas XI di SMK PGRI 4 Denpasar.

\section{METODE}

Desain yang digunakan dalam penelitian ini adalah analitik korelasi dengan metode pendekatan cross sectional study. Populasi dalam penelitian ini adalah seluruh remaja putri kelas XI SMK PGRI 4 Denpasar dengan jumlah sampel 109 responden. Teknik pengambilan sampel dalam penelitian ini menggunakan metode Nonprobability Sampling dengan teknik Total Sampling. Pengumpulan data dilakukan secara online menggunakan kuesioner body image dan pola makan dalam link google form pada tanggal 22-26 Maret 2021. Kriteria inklusi dalam penelitian ini yakni siswi yang bersedia menjadi responden dan menyetujui informed consent yang telah diberikan melalui google form.

Analisis data dalam penelitian ini dibedakan menjadi analisis univariat dan bivariat. Uji statistik yang digunakan untuk mendapatkan hubungan antara kedua variabel adalah statistik Nonparametric Test yaitu Spearman Rho's karena data tidak berdistribusi normal.

\section{HASIL}

\section{Karakteristik Responden}

Pada tabel 1. di atas dapat dilihat bahwa dari 109 responden, kelompok umur 17 tahun merupakan responden paling banyak dengan jumlah $72(66,1 \%)$ responden. Jurusan Tata Boga sebanyak $50(45,9 \%)$ responden lebih mendominasi dari pada responden dengan jurusan yang lain.

Tabel 1. Karakteristik Umum Responden Remaja Putri Kelas XI Di SMK PGRI 4 Denpasar $(\mathrm{n}=109)$

\begin{tabular}{lll}
\hline Karakteristik & f & \% \\
Umur (tahun) & & \\
16 & 30 & 27,5 \\
17 & 72 & 66,1 \\
18 & 7 & 6,4 \\
Jurusan & & \\
$\quad$ Akomodasi Perhotelan & 44 & 40,4 \\
Multi Media & 15 & 13,8 \\
$\quad$ Tata Boga & 50 & 45,9 \\
\hline
\end{tabular}

\section{Hasil Penelitian Variabel}

Pada tabel 2. di atas menunjukkan bahwa body image remaja putri kelas XI di SMK PGRI 4 Denpasar sebagian besar yaitu 60 (55\%) responden dalam kategori negatif yang mana artinya persepsi, pikiran, dan perasaan menyimpang seseorang terhadap ukuran, penampilan dan fungsi tubuhnya.

Tabel 2. Body Image Remaja Putri Kelas XI Di SMK PGRI 4 Denpasar ( $\mathrm{n}=109)$

\begin{tabular}{lll}
\hline Body Image & f & \% \\
\hline Positif & 49 & 45 \\
Negatif & 60 & 55 \\
\hline
\end{tabular}

Pada tabel. 3 di atas menunjukkan bahwa pola makan remaja putri kelas XI di SMK PGRI 4 Denpasar sebagian besar yaitu 58 $(53,2 \%)$ responden dalam kategori buruk yang mana artinya kebiasaan sehari-hari lebih banyak mengonsumsi makanan dan minuman yang kurang bergizi seimbang, frekuensi makan yang kurang dan jadwal makan tak teratur sehingga tidak bermanfaat bagi tubuh.

Tabel 3. Pola Makan Remaja Putri Kelas XI Di SMK PGRI 4 Denpasar ( $\mathrm{n}=109)$

\begin{tabular}{lll}
\hline Pola Makan & $\mathbf{f}$ & $\mathbf{\%}$ \\
\hline Baik & 51 & 46,8 \\
Buruk & 58 & 53,2 \\
\hline
\end{tabular}

Tabel 4. Hubungan Antara Body Image dengan Pola Makan Remaja Putri Kelas XI Di SMK PGRI 4 Denpasar (n=109)

\begin{tabular}{llll}
\hline & & $\begin{array}{l}\text { Body } \\
\text { Image }\end{array}$ & $\begin{array}{l}\text { Pola } \\
\text { Makan } \\
\text { Body Image }\end{array}$ \\
& $\mathrm{r}$ & 1.000 & 0.710 \\
Pola Makan & $\mathrm{p}$ & & 0.000 \\
& $\mathrm{r}$ & 0.710 & 1.000 \\
& $\mathrm{p}$ & 0.000 &
\end{tabular}

Tabel 4. Menunjukkan bahwa nilai correlation coefficient (kekuatan korelasi) sebesar 0,710 , nilai sig(nilai $p<0,001$ dan arah korelasi positif $(+)$. Dari hasil tersebut dapat disimpulkan bahwa nilai $\mathrm{p}<0,005 \quad(\mathrm{p}<0,05)$ maka Ha diterima, yang artinya ada hubungan yang signifikan antara body image dengan pola makan remaja putri kelas XI di SMK PGRI 4 Denpasar. Hubungan ini di-

Jurnal Riset Kesehatan Nasional hal. 89 
ditunjukkan dengan kekuatan korelasi ( $\mathrm{r}=$ 0,710 ) yang termasuk ke dalam kategori kuat $(0,60-0,799)$, dengan arah korelasi positif $(+)$. Hal ini berarti apabila semakin positif body image remaja putri, maka semakin baik pola makan remaja putri.

\section{PEMBAHASAN \\ Body Image Remaja Putri}

Pada penelitian body image remaja putri kelas XI di SMK PGRI 4 Denpasar ini dapat dibedakan menjadi dua kategori yaitu body image positif dan negatif. Dari 109 responden pada penelitian ini, sebanyak $49(45 \%)$ responden memiliki body image positif sedangkan sebanyak $60(55 \%)$ responden memiliki body image negatif. Hal ini menunjukkan bahwa sebagian besar responden remaja putri pada penelitian ini tergolong memiliki body image yang negatif. Persepsi negatif remaja putri dikarenakan tidak puas dengan penampilannya saat ini dengan adanya perubahan bentuk tubuh akibat penambahan lemak/kekurangan lemak yang mana menyebabkan remaja putri merasa gemuk/kurus. Kekhawatiran berat badan bertambah didukung dari hasil penelitian yang dilakukan oleh Irawan \& Safitri (2014), yang menyatakan bahwa remaja putri memiliki body image negatif sebanyak $23 \%$ dengan dimensi kekhawatiran menjadi gemuk, merasa cemas terhadap berat badan yang bertambah, dan kecenderungan melakukan diet serta membatasi pola makan yang cenderung tinggi.

Dilihat dari pernyataan kuesioner penelitian ini yang mana sebanyak 43 $(39,4 \%)$ responden menyatakan sangat setuju terhadap pernyataan "saya khawatir menjadi gemuk". Hal tersebut dikarenakan mayoritas remaja putri ingin memiliki tubuh ideal, langsing dan menarik. Penelitian yang telah dilakukan oleh Sunartio, Sukamto \& Dianovinina (2012) menyatakan bahwa individu yang sering melakukan perbandingan sosial seperti membandingkan bentuk tubuhnya dengan bentuk tubuh orang lain yang mana objek pembandingnya ialah tubuh perempuan lain yang lebih menarik. Sehubungan dengan membandingkan bentuk tubuh terhadap perempuan lain yang lebih menarik tersebut akan meningkatkan ketidakpuasan bentuk tubuh pada remaja perempuan.

Berdasarkan hasil penelitian kuesioner sebanyak $68(62,4 \%)$ responden menyatakan sangat tidak setuju pada pernyataan "puas dengan bagian tubuh bagian tengah (dari pinggang hingga perut) hal ini disebabkan apabila individu dengan berat badan berlebih akan mempunyai lemak berlebih yang bisa menyebabkan perut buncit". Jika individu mengonsumsi lebih banyak kalori daripada yang dibakar, berat badannya akan bertambah dengan gaya hidup yang tidak aktif menyulitkan individu untuk membuang lemak berlebih, terutama di perut. Menurut Levine \& Smolak dalam Hanum, Nurhayati, \& Riani (2014) menyatakan bahwa 40\% hingga 70\% remaja perempuan merasakan ketidakpuasan pada dua atau lebih dari bagian tubuh, khususnya pada bagian perut, pinggul, pantat dan paha.

Temuan dalam penelitian ini sejalan dengan penelitian yang dilakukan oleh Adinda, Surdayati, \& Siagian (2019) di sekolah menengah kejuruan daerah Sumatera Utara. Penelitian tersebut mencatat mayoritas 56,7\% responden memiliki body image negatif. Dalam penelitiannya menyebutkan bahwa remaja putri berpersepsi negatif karena banyak yang sudah memiliki status gizi normal namun masih merasa tubuhnya kurus. Sementara itu, hasil penelitian ini bertolak belakang dengan penelitian yang dilakukan oleh Anggraeni (2015) yang berjudul "Hubungan antara Body Image dengan Frekuensi Makan, Jenis Makanan dan Status Gizi Remaja Putri di SMA N 7 Surakarta" menunjukkan bahwa hasil body image pada remaja putri yang dijadikannya responden lebih banyak memiliki body image positif.

\section{Pola Makan Remaja Putri}

Pada penelitian pola makan remaja putri kelas XI di SMK PGRI 4 Denpasar ini dapat dibedakan menjadi dua kategori yaitu pola makan baik dan buruk. Dari 109 responden pada penelitian ini, sebanyak $51(46,8 \%)$ responden memiliki pola makan baik sedangkan sebanyak $58 \quad(53,2 \%)$ responden memiliki pola makan buruk. Hal ini menunjukkan bahwa mayoritas responden remaja putri pada penelitian ini tergolong mengalami pola makan yang buruk akibat dari kegiatan atau aktivitas remaja yang tidak sempat makan secara teratur dan adanya remaja putri yang mengalami body image negatif sehingga memengaruhi pola makan. Remaja putri cenderung membatasi konsumsi makan karena adanya ketidakpuasan terhadap bentuk tubuhnya. Menurut William dalam Chairiah (2012) mengatakan bahwa perubahan bentuk tubuh pada masa remaja akan menimbulkan kecemasan pada mereka

Jurnal Riset Kesehatan Nasional hal. 90 
yang sadar sehingga membuat mereka mengontrol pola makannya. Selain itu juga, pola makan buruk disebabkan oleh meningkatnya aktivitas sosial serta kesibukan remaja yang akan berpengaruh pula pada pola makan mereka (Suyasmi, Citrawathi \& Sutajaya, 2018).

Berdasarkan hasil penelitian kuesioner sebanyak $73(67 \%)$ responden menyatakan kadang-kadang pada pernyataan "saya makan 3 kali perhari", hal ini disebabkan oleh kebiasaan makan pada remaja putri sering kurang ideal karena kesibukan yang dimilikinya, tekanan dari lingkungan sosial, dan masa pencarian identitas. Selain itu juga, dari hasil penelitian kuesioner sebanyak 33 (30,3\%) responden menyatakan selalu "pada malam hari saya hanya makan buah-buahan" dan sebanyak $51(46,8 \%)$ responden menyatakan kadang-kadang "saya sarapan setiap hari". Hal ini juga menjadi pendukung untuk berkurangnya frekuensi pola makan remaja putri kelas XI di SMK PGRI 4 Denpasar. Menurut Adinda, dkk. (2019) mengatakan bahwa ketakutan akan menjadi gemuk menyebabkan remaja putri melewatkan waktu makan pagi (sarapan) dan makan malam yang mana perilaku ini dianggap sebagai langkah awal untuk menurunkan berat badan.

Pola makan yang baik perlu dibentuk sebagai upaya untuk memenuhi kebutuhan gizi. Pola makan yang tidak sesuai akan menyebabkan asupan gizi berlebih atau sebaliknya. Asupan berlebih dapat menyebabkan kelebihan berat badan dan penyakit lain yang disebabkan oleh kelebihan zat gizi. Sebaliknya asupan makan kurang dari yang dibutuhkan akan menyebabkan tubuh menjadi kurus dan rentan terhadap penyakit (Sulistyoningsih, dalam Anggraeni 2015).

Hasil penelitian ini sejalan dengan penelitian Setyawati dan Setyowati (2015) pada remaja putri di sekolah menengah pertama daerah Jawa Tengah menunjukkan bahwa $51 \%$ responden mengalami pola makan yang buruk. Dalam penelitiannya menyebutkan bahwa pola makan buruk disebabkan oleh pengetahuan gizi yang kurang dan persepsi remaja yang negatif akan bentuk tubuhnya. Namun., hal ini bertolak belakang dengan penelitian yang dilakukan oleh Chairiah (2012) pada remaja putri daerah Jakarta yang menunjukkan hasil mayoritas responden mengalami pola makan baik sebanyak $66,3 \%$.

Berkaitan dengan hasil penelitian diatas, dampak dari pola makan buruk yakni ter- sumbatnya proses pertumbuhan dan perkembangan pada remaja putri akibat dari ketidakseimbangan gizi yang didapatkan untuk tubuhnya. Menurut Setyawati \& Setyowati (2015), masalah kesehatan yang akan muncul dari pola makan buruk antara lain penurunan konsentrasi belajar, risiko melahirkan bayi dengan BBLR, dan penurunan kesegaran jasmani hingga mengalami anemia.

\section{Hubungan Antara Body Image Dengan Pola Makan Remaja Putri Kelas XI Di SMK PGRI 4 Denpasar}

Penelitian ini menunjukkan hasil terdapat hubungan yang signifikan antara body image dengan pola makan remaja putri kelas XI di SMK PGRI 4 Denpasar. Hubungan ini ditunjukkan dengan kekuatan korelasi kuat ( $\mathrm{r}=$ $0,710)$ dengan arah korelasi positif $(+)$ yang berarti semakin positif body image remaja putri, maka semakin baik pola makan remaja putri. Begitu pula sebaliknya, jika semakin negatif body image remaja putri, maka semakin buruk pola makan remaja putri. Hal ini menunjukkan bahwa pola makan remaja putri dipengaruhi oleh body image yang dimiliki oleh remaja putri tersebut.

Body image sangat berperan penting bagi remaja dalam membentuk pola makan yang baik. Remaja yang memiliki body image positif tidak mempermasalahkan dalam pembatasan pola konsumsi makanan karena mereka berpikir bahwa bentuk tubuhnya baik-baik saja. Body image yang positif akan menimbulkan pengaruh positif pula bagi kesejahteraan fisik maupun psikis remaja. Menurut Yusinta, Pradigdo, \& Rahfiludin (2019) beranggapan bahwa hal tersebut bertolak belakang jika gambaran negatif seorang remaja atas citra diri (body image) yang mana artinya remaja tidak puas pada bentuk tubuh yang mereka miliki. Remaja dengan body image negatif beranggapan bahwa mereka telah mengalami kekurangan atau kelebihan berat badan diatas rata-rata. Banyak remaja mengharapkan berat badan yang turun dengan cepat melalui diet yang ketat namun tidak disesuaikan dengan gizi yang dibutuhkan yang mana dapat menimbulkan suatu penyakit. Banyak dari remaja berkeinginan memiliki bentuk badan serupa dengan yang mereka idolakan seperti selebriti, peragawati, atau artis mayoritas yang bertubuh langsing, tinggi, dan ideal.

Hasil penelitian ini sejalan dengan penelitian yang dilakukan oleh Asnuddin \&

Jurnal Riset Kesehatan Nasional hal. 91 
Sanjaya (2018) dengan judul hubungan tingkat kecemasan dan body image dengan pola makan remaja putri di SMA Negeri 2 Sidrap yang menunjukkan bahwa ada hubungan yang signifikan antara body image dengan pola makan remaja putri di SMA Negeri 2 Sidrap tahun 2018. Hasil penelitian di atas juga didukung oleh penelitian yang dilakukan Oktaviyani (2015) yang berjudul hubungan body image dengan pola makan remaja putri di SMA Muhammadiyah 7 Yogyakarta. Penelitian tersebut menemukan hasil analisis yang dapat disimpulkan bahwa ada hubungan antara body image dengan pola makan remaja putri.

\section{KESIMPULAN DAN SARAN \\ Kesimpulan}

Dari hasil penelitian dan pembahasan dapat ditarik kesimpulan terdapat hubungan yang bermakna antara body image remaja putri dengan pola makan remaja putri Kelas XI Di SMK PGRI 4 Denpasar.

\section{Saran}

Diharapkan kepada remaja putri Kelas XI SMK PGRI 4 Denpasar dapat menjadi bahan masukan untuk remaja putri yang mana dari persepsi mengenai body image yang negatif dari dalam diri atau lingkungan luar dijadikan pemicu untuk tampil lebih baik dengan menggali kelebihan dari dalam dirinya dalam meningkatkan bakat dan kemampuan diri sehingga memiliki kepercayaan diri yang baik serta memperluas pergaulan dengan para remaja putri lainnya untuk menunjang terciptanya body image positif sehingga memicu untuk terjadinya pola makan serta gaya hidup yang baik.

Kepada pihak sekolah perlu adanya konseling ataupun sosialisasi mengenai proses tumbuh dan kembang kesehatan remaja yang kompleks, khususnya pola makan dan body image melalui lingkungan sekolah dan guru yang mana merupakan role model bagi anak didiknya untuk mengurangi angka kejadian pola makan yang buruk serta body image negatif.

Bagi peneliti selanjutnya hasil penelitian ini bisa digunakan sebagai sebagai bahan pertimbangan untuk lebih memperdalam penelitian selanjutnya menggunakan faktorfaktor yang mempengaruhi body image maupun pola makan dengan variabel yang berbeda seperti apakah ada hubungan pengaruh berat badan dan persepsi gemuk atau kurus terhadap pola makan remaja putri.

\section{KEPUSTAKAAN}

Adinda, D., Sudaryati, E., \& Siagian, A. (2019). Gambaran kebiasaan makan, body image dan status gizi remaja putri di SMK Negeri 2 Sibolga. Journal of Public Health and Coastal Health. 2(1). 39-50.

Anggraeni, S. D. (2015). Hubungan antara body image dengan frekuensi makan, jenis makanan dan status gizi remaja putri di SMA negeri 7 surakarta. Jurnal Ilmu Kesehatan. 1-12.

Asnuddin \& Sanjaya. (2018). Hubungan tingkat kecemasan dan body image dengan pola makan remaja putri di SMA negeri 2 sidrap. Jurnal Ilmiah Kesehatan Pencerah. 7(2).

Batubara, J. (2016). Adolescent development (perkembangan remaja). Diperoleh tanggal 23 Januari 2021, dari https:// www.researchgate.net/ publication/312175400_Adolescent_Developm entPerkembangan_Remaja

Chairiah, P. (2012). Hubungan gambaran body image dan pola makan remaja putri di SMAN 38 Jakarta. Skripsi. Fakultas Ilmu Keperawatan Universitas Indonesia.

Gloria, L. (2019). Gambaran pola makan dan status gizi remaja di SMP Advent Lubuk Pakam.Jurnal Penelitian dan Pengabdian Masyarakat UISU. 8(2)

Hanum, Nurhayati, \& Riani. (2014). Pengaruh body dissatisfaction dan selfesteem dengan perilaku diet mahasiswi universitas " $\mathrm{x}$ " serta tinjauan dalam islam. Jurnal Psikogenesis Fakultas Psikologi Universitas YARSI. 2(2). 180190

Irawan, S.D., \& Safitri. (2014). Hubungan antara body image dan perilaku diet mahasiswi universitas esa unggul. Jurnal Psikologi. 12(1). 18-25

Kementrian Kesehatan Republik Indonesia. (2018). Menkes: remaja Indonesia harus sehat. Jakarta: Kemenkes RI 2018

Mardalena, I. (2017). Dasar - dasar ilmu gizi dalam keperawatan. Yogyakarta: Pustaka Baru Press

Mulyati, S. (2018). Pengetahuan dan sikap tentang makanan serta pola makan pada siswa kelas XI SMK N 4 Yogyakarta. Ejournal Student Pendidikan Teknik Bo-

Jurnal Riset Kesehatan Nasional hal. 92 
Boga. 7(4).

Neagu, A. (2015). Body image: a theoritical framework. Romania: The Publishing House of The Romanian Academy

Oktaviyani, T. (2015). Hubungan body image dengan pola makan remaja putri di SMA Muhammadiyah 7 Yogyakarta. Jurnal Ilmu Keperawatan.

Rahman, N., Dewi, N. U., \& Armawaty, F. (2016). Faktor-faktor yang berhubungan dengan perilaku makan pada remaja SMA Negeri 1 Palu. Jurnal Kesehatan Masyarakat. 7(1). 43-52

Ritonga, E. R. H. (2014). Pengaruh gaya hidup terhadap berat badan ideal pada remaja putri sekolah menengah atas (SMA) negeri 4 Medan. Skripsi. Pendidikan Kesejahteraan Keluarga Fakultas Teknik Universitas Medan.

Setyawati, V. A. V., \& Setyowati, M. (2015). Karakter gizi remaja putri urban dan rural di Provinsi Jawa Tengah. Jurnal Kesehatan Masyarakat.11(1).

Sunartio, L., Sukamto, M., \& Dianovinina, K. (2012). Sosial comparison dan body dis- satisfaction pada wanita dewasa awal. Jurnal Psikologi Indonesia. 9(2). 161166.

Suryani, D., Hafiani, R., \& Junita, R. (2015). Analisis pola makan dan anemia gizi besi pada remaja putri Kota Bengkulu. Jurnal Kesehatan Masyarakat Andalas. 10(1). 11-18.

Suyasmi, N. M, Citrawathi, D. M, \& Sutajaya, I. M. (2018). Hubungan pola makan, aktivitas fisik, pengetahuan gizi dengan indeks massa tubuh (IMT) siswa kelas XI MIPA SMA N 4 Singaraja. Jurnal Pendidikan Biologi UNDIKSHA. 5(3). 156-165.

UNICEF Indonesia. (2019). Peringatan UNICEF: diet buruk merusak kesehatan anak di seluruh dunia. Jakarta: UNICEF Indonesia

Yusinta, D. H., Pradigdo, S. F., \& Rahfiludin, M. Z. (2019). Hubungan body image dengan pola makan konsumsi dan status gizi remaja putri di SMPN 12 Semarang. Jurnal Kesehatan Masyarakat. 7(2). 47-5 